\title{
Luther Øre - trosopplæring med Luther som inspirator
}

Unge mennesker i dagens kirke - hva tenker de om troen? Om kirken? Om fremtiden? Ideen bak prosjektet «Luther Øre» er å gi rom for ungdommers virkelighet, gi hjelp til refleksjon og til å kunne formulere tro og tanker. Noen av disse ordene ønsker vi også ut $i$ det offentlige rom. Dette vil vi gjøre med Luther og reformasjonsjubileet som bakteppe.

Av INGER BoRE, rådgiver for undervisning og trosopplcering i Tunsberg bispedømme, e-post: ib628@kirken.no

ToRe Dvergastein, kulturrådgiver i Tunsberg bispedømme, e-post: td488@kirken.no

TID FOR REFLEKSJON OG UNDRING Trosopplæringsreformen har store ambisjoner i møte med barn og unge. Mye skal læres om kirkens tro og tradisjon. Det kan gjøre at formidlere opplever at de må være «gjerrige» på tidsbruk slik at barn og unge får med seg mest mulig innhold på ofte korte møtepunkter. Men en slik praksis har en mulig slagside; det blir lite rom for refleksjon og undring, som jo er en av reformens målsettinger.

I Plan for trosopplæring, «Gud gir vi deler» leser vi følgende under punktet «livstolkning og livsmestring»: «livsmestring handler om å møte livet i gode og onde dager. $\AA$ ha tro på egne ressurser og håp for fremtiden. $\AA$ være skapt og elsket av Gud gir grunnlag for et slikt håp» (Kirkerådets plan for trosopplæring, 2010 side 14).

Å nå dette målet krever gjerne refleksjon og arbeid over noe tid. I Tunsberg bispedømme begynte vi i 2013 å se på muligheten for å jobbe mer med «livstolkning og livsmestring». Vi leter alltid etter meningsfulle sammenhenger å jobbe i, og med det kommende reformasjonsjubileet og Martin Luthers liv og virke fant vi en god ramme.
I prosjektet «Luther øre» ønsker vi kunnskap, ro og tid nok til at ungdommer skal få tenke seg om både en og flere ganger. Prosjektets målsetting er inspirert av hva Martin Luther selv gjorde. Vi utfordrer ungdom til å

- sette egne ord på troen

- lage teser om kirken og om egen tro og fremtid

\section{Prosjektets tilblivelse}

Tunsberg bispedømme ved kulturrådgiver samt rådgiver for undervisning og tros-opplæring hadde ideen og søkte midler for à sette i gang arbeidet. Vi inviterte med oss fire ulike menigheter i bispedømmet: Ål, Strøms $\emptyset$ i Drammen, Holmestrand og Tjøme.

Menighetene ble spurt om å være med på et prosjekt som skulle gå over to år, der de forpliktet seg til å samle noen litt større barn eller ungdommer og sette på dagsorden refleksjon rundt egen tro, samt komme frem til teser. Vi satte også som mål at tesene skulle være synlig i det offentlige rom. Vi oppfordret ikke til å lage et eget tiltak der «Luther Øre» var tema, men at man jobbet med dette innenfor rammen av 
tilbud som allerede fantes i menigheten; Lys våken, konfirmantarbeid, konfirmantreunion, ungdomsgrupper.

Vi fra bispedømmets side forpliktet oss på å gi de nødvendige ressurser til menighetene for å få dette til. Vi inviterte til en oppstartssamling over tre døgn samt halvårlige døgnsamlinger for de fire menighetene som deltar, og to ansatte fra hver menighet forpliktet seg til å være med. På disse samlingene har vi lagt vekt på å gi kunnskap om Martin Luther og reformasjonen, samt skape en kultur for deling.

Vi utarbeidet noen aktuelle spørsmål menighetene kunne jobbe med:

- Hva ved Martin Luthers liv og virke vil dere legge vekt på? Hans opprør mot det etablerte? Hans mot til å stille spørsmål? Hans åndelige opplevelse? A være utst $\varnothing \mathrm{tt}$ ?

- Hvis du skulle slå opp et budskap på en dør i det offentlige rom - hvilket budskap er det viktigste? Det kan være innenfor rammen av kristentro og kirke - eller samfunnet generelt.

- Hvordan er det å være kristen ungdom i dag? Hva svarer vi om noen spør hva vi tror på? Kan jeg finne min egen vei til troen som jeg kan våge å tenke er god nok?

De fire menighetene fikk stor frihet til å forme de lokale prosjektene slik det passet best for dem innenfor den gitte rammen. Her oppfordret vi til å ta hensyn til lokale forhold, bemanning, geografi og annet. Hva endte de ulike menighetene opp med à gjøre?

\section{$\AA_{\mathrm{L}}$}

Martin Luthers spørsmål «hvordan finne en nådig Gud» ble utgangspunktet på Ål.
For hva er egentlig en nådig Gud? Hva er nåde? I dag? Er vi nådige? Trenger vi nåde? Konfirmanter ble invitert til å være «Lutherkonfirmanter», og fire meldte seg. Disse fire jobber med ordet NÅDE, både sammen med resten av konfirmantene og som egen gruppe. De ti bud blir brukt som bakgrunn; ingen klarer å holde budene, og vi trenger alle nåde. Hva er så nåde? Forstår vi det lettere om vi setter det sammen med ordet «nådeløst»?

På Ål blir blant annet film og intervju benyttet som metode, og konfirmantene går på den lokale matbutikken og intervjuer kunder i butikken, der de spør dem om å forklare ordet «nåde». Det viser seg at mange synes det er vanskelig, og at nåde for mange er et ganske uforståelig ord. En ting er å gi et eksempel på hva det er å være nådig - men hva er ordets egentlige innhold? Dermed grubler konfirmantene videre på det og med hvordan de selv vil forklare ordet NÅDE. Seks korte setninger er til nå resultatet. Disse er trykket på skilt med egen design og skal være synlig i Ål sentrum en tid fremover.

Ål har nå utviklet et ferdig konfirmantopplegg med NÅDE-tema.

\section{TJøMe}

På Tjøme velger man å jobbe ut fra ideen om en NATTKIRKE som har et ganske annet preg enn «dagkirken» søndag kl 11.

Tenker ungdom i dag på Gud? Hvordan skal ungdom tenke på Gud i det hele tatt? Gir kirken rom for de store spørsmålene, eller kommer vi med ferdigtygde svar? Med Nattkirken $\emptyset$ nsker menigheten å skape en arena som senker hverdagstempoet og gir ungdom tid til å tenke selv. Man lager et møtested hvor ungdom kan sanse Gud; høre, lukte, se og føle. Et nøkkelord for prosjek- 
tet på Tjøme er troshistorie, og et langsiktig arbeid er i gang der man startet en kultur for å dele troshistorie med hverandre.

Hvordan kan en legge til rette for denne tryggheten? Står kirkens rom og tradisjoner i veien for dette? Tjøme menighet $\emptyset$ nsker å legge til rette for at ungdom skal være tro mot seg selv og å tørre å ha tillit til sine egne trosoppdagelser. Når NATTKIRKE arrangeres, ominnredes en tradisjonell langkirke med små kafébord i midtgangen, annen belysning, mat og rom for samtaler. Tema som blir snakket om: hva skal til for at du skal gå i kirken, gudsbilde, selvbilde, Luther, teser, troshistorie, livsvisjon. Martin Luther arbeidet selv med gudsbilde, dels i opposisjon til datidens forståelse og betoninger. Luthers troshistorie er en reise i det å være tro mot seg selv og å tørre å ha tillit til sine egne trosoppdagelser. Ut fra disse samtalene og NATTKIRKEsamlingene er det laget teser som skal vises som videomapping på utsiden av Tjøme kirke.

\section{$\mathbf{S}_{\text {TR }} \emptyset \mathrm{MS} \emptyset$}

I Strøms $\emptyset$ menighet i Drammen tok man utgangspunkt i spillkulturen der rollespill er en utbredt aktivitet. Med det som bakgrunn har man utviklet et kortspill: Lutherspillet. Målet med spillet er at ungdommer skal få kontakt med sine tanker om Gud, kirka, tro og sitt eget liv. Det er et håp at spillet kan gi ungdom hjelp til å komme et lite stykke videre i sin trosvandring .

Spillets omfang er basert på at en skal rekke fire spillsamlinger på en spillrunde, slik at det passer godt å bruke på for eksempel en konfirmantleir. Det er også mulig å endre dette slik at det kan gå over et lengre eller kortere tidsspenn. Spillet er også laget med et konkurransemoment. I spillet deler man ut kort med ulike roller i persongalleriet rundt Martin Luther, og deltagerne i spillet får dermed ulike roller. Gjennom spillet skal man løse oppgaver og lage teser. En oppgave er for eksempel å snakke om gudsbilde med en uttalelse fra Martin Luther som utgangspunkt: spørsmålet blir så om spilldeltagerne er enig eller uenig i gudsbildet som blir presentert. Videre snakker konfirmantene om hvilket gudsbilde de har med seg, og hva som former våre gudsbilder. Tesene som formes i Strøms $\varnothing$, skal henges opp på kirkedøren samt på lokale digitale dører.

\section{Holmestrand}

Holmestrand menighet plantet for noen år siden et tre i Lutherhagen i Wittenberg, og menigheter som gjør det, forplikter seg også til å plante et slikt tre ved sin egen kirke. I Holmestrand tar man utgangspunkt i reformasjonsdagen og markerer den årlig med konfirmantene. Som luthersk kirke er vi en del av en verdensomspennende enhet og hører sammen med andre. Konfirmantene får være med og mene noe om hva det betyr for oss i dag. Som en oppfølger bruker man også Luther-tema på konfirmant-reunion.

Fjorårskonfirmantene blir invitert til en kveld med mye forskjellig innhold, blant annet et mini-foredrag om Martin Luther og hans samtid, dramaet i hans liv. Selvsagt er også tesene et tema. Deretter går fjorårskonfirmantene i grupper, hver gruppe skal så komme frem til to felles teser som blir hengt opp på en dør. Det blir gode og spennende samtaler for å komme frem til tesene. Det kan være mange ting som er viktige å «melde» - men hva er det viktigste? Når praten først kommer i gang, er 
erfaringen at en skulle hatt lenger tid til prosessen. Ungdommene signaliserer at det er spennende å tenke at man er en reformator. I Holmestrand skal to teser freses $\mathrm{i}$ stein foran Botne kirke, og blir dermed stående for alltid.

\section{Avslutining}

Å lage teser kan man gjøre på få minutter, og et spørsmål som «hva er ditt viktigste budskap til kirken» kan få frem mange umiddelbare reaksjoner. Men det blir en annen dynamikk om man har lenger tid til disposisjon. Å tenke gjennom ting en gang til, å skape rom der det er trygt å komme frem med tro og tanker, det krever gjerne flere møter.

Uansett: om man skal invitere til refleksjon og til å lage teser, er det viktig å ta imot det som kommer. Vår oppgave er å ta imot meldingene og være med på videre refleksjon. Ungdommer kan være uenige seg imellom, og vi kan være uenige med dem. Dette er utgangspunkt for mange gode samtaler, så vi håper flere kan tenke seg å prøve å være «Luther øre». 